\title{
Teachers' and Educational Administrators' Conceptions of Inquiry: Do They Promote or Constrain Inquiry-Based Science Teaching in Junior High Schools?
}

\author{
Salifu Maigari Mohammed ${ }^{1, *} \&$ Kwaku Darko Amponsah ${ }^{1}$ \\ ${ }^{1}$ Department of Teacher Education, School of Education and Leadership, College of Education, University of Ghana, \\ Legon-Accra, Ghana \\ *Correspondence: Department of Teacher Education, School of Education and Leadership, College of Education, \\ University of Ghana, P. O. Box LG 1181, Legon-Accra, Ghana. Tel: 233-242-984-946. E-mail: \\ smmohammed@ug.edu.gh
}

Received: March 1, 2021

Accepted: July 4, 2021 Online Published: August 17, 2021

doi:10.5430/jct.v10n3p58

URL: https://doi.org/10.5430/jct.v10n3p58

\begin{abstract}
This study sought to examine whether teachers' and educational administrators' conceptions of inquiry promote or constrain inquiry-based science teaching in junior high schools. The study also explored any connections between participants' conceptions of scientific inquiry, inquiry teaching, and inquiry learning. Multiple-case study involving semi-structured interviews was used to collect data from 18 integrated science teachers and 23 educational administrators from rural and urban areas in the Central Region of Ghana. Analysis of the qualitative data involved open coding and categorisation of participants' responses. We found that all the teachers and educational administrators held either uninformed or partially informed conceptions of scientific inquiry and inquiry teaching and learning which, constrain inquiry-based science instruction in junior high schools. We also found that participants' conceptions of scientific inquiry reflected in their conceptions of science teaching and learning. Again, we found that the uninformed conceptions of inquiry developed from participants' lack of exposure and experiences with inquiry-based science instruction when they were students. We recommend regular explicit-reflective in-service trainings to promote teachers' and educational administrators' conceptions and teachers' practice of inquiry-based science teaching. We also recommend reforms in preservice science education that emphasise the engagement of prospective teachers in collaborative explicit-reflective inquiry investigations and instructional practices.
\end{abstract}

Keywords: scientific inquiry, inquiry teaching, inquiry learning, teachers' conceptions, educational administrators' conceptions, junior high school

\section{Introduction}

The desire of science education researchers to identify meaningful and effective teaching and learning strategies to promote scientific literacy cannot be overemphasised (Abd-El-Khalick, 2013; Anamuah-Mensah, 2012; Shumba, 1999). Notwithstanding, researchers are also concerned about the effective implementation of teaching and learning strategies in classrooms.

A major contemporary goal of science education globally is to engage learners in inquiry-based activities to develop their understandings and abilities to conduct scientific inquiry to make them scientifically literates (Chabalengula \& Mumba, 2012; Dogan \& Abd-El-Khalick, 2008; Fitzgerald, Danaia, \& McKinnon, 2019; National Research Council [NRC], 1996, 2000, 2012). The expectations are that scientifically literate graduates will contribute meaningfully to development, show concern for living things, become responsible for the quality of the environment, and demonstrate appreciation and desire to conserve natural balance (Curriculum Research and Development Division [CRDD], 2007, p. ii). However, evidence show that many students have limited abilities to conduct inquiries (Hume \& Coll, 2010; Mohammed, Amponsah, Ampadu, \& Kumassah, 2020; Stone, 2020) and hold naïve conceptions of inquiry (Dogan \& Abd-El-Khalick, 2008; J. S. Lederman \& N. G. Lederman, 2017; Lederman et al., 2014).

Challenges constraining teachers from enacting instruction that promote students' conceptions and abilities to 
conduct inquiry include inadequate conceptions and pedagogical conceptions of inquiry held by the teachers themselves (Abell \& Smith, 1994; Aguirre, Haggerty, \& Linder, 1990; Haefner \& Zembal-Saul, 2004), and lack/limited administrative support for inquiry teaching (Crawford, 2007; Johnson, 2007). Empirical evidence from many contexts show that, prior to constructivist professional developments and methods courses, many preservice and in-service teachers lacked the prerequisite and necessary conceptions to enact inquiry-based instruction (Choi \& Ramsey, 2009; Crawford, 2007; Haefner \& Zembal-Saul, 2004).

Unfortunately, there have been few studies in many other contexts, including Africa, to examine preservice and in-service teachers' conceptions of inquiry (Chabalengula \& Mumba, 2012; Mokiwa \& Nkopodi, 2014; Mugabo, 2012; Ssempala, 2017). While the effectiveness of inquiry instruction is widely acknowledged (Furtak, Seidel, Iverson, \& Briggs, 2012) and many countries are seeking to adopt and implement this pedagogical approach (Chabalengula \& Mumba, 2012; CRDD, 2007, 2012), it is uncertain whether many teachers hold the informed conceptions and pedagogical conceptions required for inquiry instruction. Again, there is little evidence to show whether many educational administrators hold the informed conceptions required to provide mentorship, support, and feedback for inquiry teaching in schools.

\subsection{Purpose of the Study}

This study sought to investigate whether teachers' and educational administrators' conceptions of scientific inquiry, inquiry teaching, and inquiry learning constrain or promote inquiry-based science instruction in junior high schools (JHSs). The study also sought to explore whether there are any connections between participants' conceptions of scientific inquiry, inquiry teaching, and inquiry learning.

\section{Conceptual Framework}

\subsection{Conceptions of Scientific Inquiry}

Anderson (2002) articulated that scientific inquiry, inquiry teaching, and inquiry learning are distinct, though related. According to Anderson scientific inquiry "reflects an understanding of how science proceeds ... independent of educational processes" (2002, p. 2). In this study, participants' conceptions of scientific inquiry, inquiry teaching, and inquiry learning were examined separately, but considered related. Again, participants' conceptions of scientific inquiry were examined independent of educational processes.

For teachers to help students understand scientific inquiry, it is prerequisite and necessary for the teachers themselves to hold informed conceptions of scientific inquiry. Teachers with informed conceptions understand that in scientific investigations individuals identify driving questions; formulate hypotheses; design investigation procedures; use tools and technology to collect, analyse, and interpret data; examine the validity and reliability of data; formulate explanations and make predications based on data; consider alternative explanations; draw conclusions; and communicate and collaborate with others (Bell et al., 2003; Capps \& Crawford, 2013; Crawford, 2000; NRC, 1996, 2000, 2012).

J. S. Lederman et al. (2014, p. 68) also noted that scientific investigations begin with questions that may or may not lead to hypotheses testing; do not follow a single set of steps for investigations; adopt procedures that are guided by the driving questions; and produce results that are influenced by the procedures. Again, J. S. Lederman et al. noted that in scientific investigations all scientists performing the same procedures may not get the same results; conclusions from research must be consistent with the data collected; explanations are developed from combination of data collected and what is already known; and scientific data are not the same as scientific evidence.

In the current study, participants' conceptions of scientific inquiry were examined in reference to the essential features of inquiry outlined in the literature. Again, this study examined participants' conceptions of scientific inquiry without their conceptions of the nature of science (NOS), although scientific inquiry is related to NOS (J. S. Lederman et al., 2014).

Empirical evidence show that many teachers hold naïve conceptions of science. They view scientific knowledge as a body of independent facts that are discovered through explorations (Abell \& Smith, 1994; Chabalengula \& Mumba, 2012; Haefner \& Zembal-Saul, 2004; Ssempala, 2017), and that scientific discoveries and explorations occur through experimentations. Naïve conceptions of science held by individuals develop mainly from traditional science instruction experiences they had when they were students (Abell \& Smith, 1994; Syer, Chichekian, Shore, \& Aulls, 2013). 


\subsection{Conceptions of Inquiry-Based Science Teaching and Learning}

For teachers to plan and enact inquiry-based science instruction, it is important for them to develop informed understandings of how to structure knowledge and create authentic learning environments that convey to students images of scientific practices resembling the works of actual scientists (Bartos \& Lederman, 2014; Syer et al., 2013). It is equally important for teachers to develop adequate conceptions of how students learn science in order to facilitate students' inquiry learning (Ireland, Watters, Brownlee, \& Lupton, 2012).

Teachers who are informed understand inquiry roles of teachers and students (Crawford, 2000; Ireland et al., 2012). They know how to facilitate, guide, coach, mentor, motivate, and direct students' inquiry. They know how to model scientific practices; collaborate with students; and innovate, experiment, and research their own instructional practices. They know the multiple and varied inquiry roles of students, including apprenticeship and planning (Crawford, 2000). They know how to design learning environments that focus on student centred experiences, teacher generated problems, and student generated questions (Ireland et al., 2012).

In contrast, teachers with traditional or limited inquiry conceptions believe that science teaching and learning involve transmission and reception of knowledge (Abell \& Smith, 1994; Haefner \& Zembal-Saul, 2004); emphasis on mastery of abstract, uncontextualized knowledge; and students' memorization and recall of content (Mokiwa \& Nkopodi, 2014). They erroneously equate hands-on activities with inquiry (Lee \& Shea, 2016). Their goals for hands-on activities are to promote students' interests and involvement rather than meaningful and conceptual learning (Haefner \& Zembal-Saul, 2004).

This study examined participants' conceptions of inquiry teaching and learning in reference to inquiry roles of teachers and students outlined in the literature.

\subsection{Preservice and In-Service Science Education}

Evidence show that appropriate preservice and in-service education is critical for developing teachers' conceptions and abilities to enact inquiry instruction. Traditional science teacher education emphasizes the transmission, reception, memorization, and recall of scientific knowledge and confirmatory hands-on activities (Johnson, 2007; Syer et al., 2013). However, constructivist teacher education emphasizes the immersion of teachers in active experiences that promote development of informed conceptions and abilities to teach inquiry (Syer et al., 2013). These include methods courses, professional developments, internships, workshops, field experiences, and seminars in which teachers take on the roles of learners (Akerson, Donnelly, Riggs, \& Eastwood, 2012; Haefner \& Zembal-Saul, 2004). They actively design and conduct authentic investigations and engage in collaborative discourse that explicitly and reflectively expose them to inquiry ideas and strategies for teaching inquiry. They also get opportunities to practice inquiry instructional planning and enactment (Crawford, 2007; Haefner \& Zembal-Saul, 2004; Maeng, Whitworth, Bell, \& Sterling, 2020).

\subsection{Support for Inquiry-Based Science Teaching and Learning}

Sustained support from researchers, administrators, and others are critical for teachers to overcome challenges associated with inquiry teaching. The supportive and non-supportive stances of mentors assigned to preservice teachers have been found to influence instructional practices of the teachers (Crawford, 2007). Similarly, the absence of district-level administrative support and failure to pay teachers' professional development stipends have been found to slow or halt the implementation of reforms in certain schools and districts (Johnson, 2007). Administrators are required to regularly observe and provide feedback on teachers' inquiry instruction. They are required to provide funding, materials, and resources (Johnson, 2007; Toolin, 2004) and be actively involved in designing school-based and district-level professional developments, workshops, and seminars that provide reflective opportunities for teachers to enhance their conceptions and inquiry instruction (Capps \& Crawford, 2013; Lotter, Harwood, \& Bonner, 2006). Science coordinators are expected to model and co-plan inquiry instruction with teachers; and coach teachers undergoing inquiry apprenticeship. (Crawford, 2007). Given the support expected from educational administrators, it is necessary for them "to be knowledgeable and experienced in using inquiry-based approaches" (Crawford, 2007, p. 619).

\section{Methods}

\subsection{Research Design}

We used multiple-case study design to examine the varied subjective meanings and understandings of inquiry participants have constructed from their complex social and educational experiences. We interacted with the 
participants in their natural settings (schools and offices) to gain insights and explain their conceptions of inquiry from their own view points (Cohen, Manion, \& Morrison, 2007; Creswell, 2009). This research design allowed us to conduct within-case analyses to explore relationships between participants' conceptions of scientific inquiry, inquiry teaching, and inquiry learning. It also enabled us to conduct meaningful cross-case analyses to identify differences and similarities between participants' conceptions.

\subsection{Sample}

We purposively sampled two rural districts, one urban and one urban-rural municipalities in the Central Region of Ghana. Then, we purposively sampled four directors of education, four science coordinators, and four circuit supervisors of education. Three directors were unavailable for interviewing and were replaced with deputy directors, while one science coordinator was unavailable and could not be replaced. We also used stratified random sampling to select 16 public and private JHSs from the districts and municipalities. All head teachers from the 16 JHSs were purposively sampled. Four head teachers were unavailable for interviewing and were not replaced. Again, we purposively sampled 16 integrated science teachers from the JHSs. Additional two teachers volunteered to participate in the study. In all, 23 educational administrators (director and deputy directors, science coordinators, circuit supervisors, and head teachers) and 18 integrated science teachers participated in this study. The goal of the sampling procedure was to obtain a set of participants that captures sufficient variations among teachers and administrators which, could facilitate meaningful cross-case analyses.

Sixteen administrators were males and seven were females. Most of the administrators' ages ranged 46-58 years. Administrators from the district education offices and government JHSs had professional teacher training with BED, BSC, MED, and MPhil qualifications. Contrary, administrators from the private JHSs had no professional training. Most of the administrators had 26-28 years working experience in education. Ten teachers were from public JHSs and eight from private JHSs. Seventeen teachers were males and one was a female. All teachers from public JHSs had professional training with DBE and BED qualifications, while all teachers from private JHSs had no professional training and were holders of WASSCE, Diploma, and HND certificates. The teachers' ages ranged 21-40 years. Most of the teachers had 2-7 years teaching experience, two had 13 years, one had 15 years, and another one had 1year teaching experiences respectively.

\subsection{Instrument}

We used semi-structured interview schedule for data collection. Some items on the schedule were used to elicit participants' demographic data and also served as ice-breaking questions. The three main items on the schedule were open-ended and required interviewees to describe their understandings of scientific inquiry, inquiry roles of teachers, and inquiry roles of students. The flexibility of the semi-structured schedule allowed participants to fully express their views and experiences as well as detailed information. It also allowed the interviewer to change the order of the questions based on participants' responses. Additionally, the semi-structured schedule allowed the interviewer to probe, prompt, and follow-up participants' responses for clarification and elaboration. It also allowed other issues and themes that emerged from the interactions to be explored (Cohen et al., 2007; Jacob \& Furgerson, 2012).

We pilot-tested the schedule using six teachers, three head teachers, a circuit supervisor, a science coordinator, and a deputy director of education from an urban municipality in the Central Region of Ghana. Participants and municipality used for the pilot test were not involved in the main study. The pilot test allowed us to refine items on the schedule. It also allowed us to check the working conditions of our recording equipment, and identified potential problems that could arise during the main data collection. This enabled us to develop contingency measures to handle problems during the main data collection.

\subsection{Data Collection Procedure}

We obtained signed consents from all four directors of education to conduct the study in JHSs and educational offices in the districts and municipalities. We also obtained signed consents from all the interviewees. We informed all the participants about the purpose of our study and sought their cooperation. We assured them of anonymity, confidentiality, privacy, and rights to refuse participation or withdraw from the study. We arranged with each participant for convenient date, time, and place for individual face-to-face interview. We visited each JHS, educational office, and participant a number of times for familiarization and establishment of rapport. This enabled the participants to open-up and talked freely. All the interviews were conducted and recorded by the corresponding author. Most of the interviews lasted about 1 hour, with a few lasting less or more than an hour.

\subsection{Data Analysis}

We transcribed all the audio recorded interviews and imported the transcripts into Nvivo (version10) for coding. We 
read each transcript and assigned open codes to identified pieces of information. Each transcript was read several times to ensure that every relevant code was identified. The coding was done iteratively to ensure consistent application of each code across the participants' responses. Additionally, each transcript was read holistically to examine the various contexts in which each code was used in the participant's responses (J. S. Lederman et al., 2014). Codes that emerged from the transcripts were compared to the essential elements of scientific inquiry, inquiry teaching (inquiry roles of teachers), and inquiry learning (inquiry roles of students) highlighted in the literature. Based on the comparisons and contexts in which the codes were used, each participant's responses about scientific inquiry, inquiry teaching, and inquiry learning were categorised either as traditional, partially informed, or fully informed conception (J. S. Lederman et al., 2014; Maeng et al., 2020).

Responses containing full descriptions of most essential elements of scientific inquiry were categorised as fully informed, responses containing some descriptions of the essential elements were categorised as partially informed, while responses containing none of the essential element of inquiry or containing positivist elements of science were categorised as uninformed. Again, responses containing full descriptions of most of the inquiry roles of students (inquiry learning) and teachers (inquiry teaching) were categorised as fully informed, responses containing some descriptions of the inquiry roles were categorised as partially informed, while responses containing none of the inquiry roles or containing traditional roles of teachers and students were categorised as traditional (Abell \& Smith, 1994; Aguirre et al., 1990; Haefner \& Zembal-Saul, 2004).

\section{Results}

Table 1 shows frequencies of emergent terms and phrases used by the teachers and educational administrators to describe their conceptions of scientific inquiry, inquiry teaching, and inquiry learning.

Table 1. Frequencies of Emergent Terms and Phrases Used by Science Teachers and Educational Administrators to Describe Scientific Inquiry, Inquiry Teaching, and Inquiry Learning

\begin{tabular}{|c|c|c|c|}
\hline \multirow{2}{*}{ Term/phrase } & \multicolumn{3}{|c|}{ Frequency of emergent terms and phrases related to: } \\
\hline & Scientific inquiry & Inquiry teaching & Inquiry learning \\
\hline Activities/practical & 8 & 6 & 10 \\
\hline Asking questions & - & 6 & 9 \\
\hline Demonstration lesson & - & 7 & - \\
\hline Directing & - & 6 & - \\
\hline Elicit/contribute prior knowledge and ideas & 2 & 10 & 7 \\
\hline Students' involvement and autonomy & - & 13 & 17 \\
\hline Give/follow instructions & - & 14 & 7 \\
\hline Guiding & - & 18 & - \\
\hline Problem identification and solution & 5 & 7 & 5 \\
\hline Lecturing & 1 & 8 & - \\
\hline Group students/work & - & 4 & 4 \\
\hline Investigation & 5 & 2 & 2 \\
\hline Supervision & - & 6 & - \\
\hline Experimenting & 4 & - & 4 \\
\hline Manipulate materials & 2 & - & 8 \\
\hline Observation & 3 & - & 1 \\
\hline Present results and findings & - & - & 8 \\
\hline Discovery & 1 & - & 2 \\
\hline Research & 8 & - & 10 \\
\hline Student-centred & 2 & - & 9 \\
\hline Critical thinking & - & - & 3 \\
\hline Exploration & - & - & 4 \\
\hline Data collection & - & - & 4 \\
\hline Facilitate learning & 1 & 7 & - \\
\hline Pay attention & - & - & 9 \\
\hline Field trips & - & 2 & - \\
\hline
\end{tabular}


Content knowledge

Responsibility for learning

Plan and design experiment

Motivating

Moderating

Leading

Monitoring

Others

\begin{tabular}{lcc}
- & 14 & - \\
- & - & 3 \\
- & - & 1 \\
- & 1 & - \\
- & 1 & - \\
- & 2 & - \\
- & 2 & - \\
1 & 7 & 6 \\
\hline
\end{tabular}

While the participants used more terms and phrases to describe inquiry teaching (27) and learning (27), they used relatively few terms and phrases to describe scientific inquiry (13). Additionally, while most participants used two or more terms and phrases to describe inquiry teaching 35(85.4\%) and learning 30(73.2\%), comparatively few used two or more terms and phrases to describe scientific inquiry $15(36.6 \%)$ (Table 2). These results suggest that the participants appeared to hold better understandings of science teaching and learning than scientific inquiry.

Table 2. Frequencies of Single and Multiple Terms and Phrases Used by Teachers and Educational Administrators to Describe Scientific Inquiry, Inquiry Teaching, and Inquiry Learning

\begin{tabular}{|c|c|c|c|}
\hline \multirow{2}{*}{ No. of terms and phrases } & \multicolumn{3}{|c|}{ Frequency of terms and phrases related to: } \\
\hline & Scientific inquiry & Inquiry teaching & Inquiry learning \\
\hline 1 & 15 & 4 & 7 \\
\hline 2 & 11 & 5 & 6 \\
\hline 3 & 2 & 6 & 8 \\
\hline 4 & 2 & 11 & 3 \\
\hline 5 & - & 7 & 7 \\
\hline 6 & - & 2 & 1 \\
\hline 7 & - & 3 & 2 \\
\hline 8 & - & - & 1 \\
\hline 9 & - & - & 1 \\
\hline 10 & - & - & 1 \\
\hline 11 & - & - & - \\
\hline 12 & - & 1 & - \\
\hline
\end{tabular}

Table 3 shows frequencies of participants holding "uninformed/traditional" and "partially informed" conceptions of scientific inquiry, inquiry teaching, and inquiry learning.

Table 3. Frequencies of Science Teachers and Educational Administrators Holding "Uninformed/Traditional" and "Partially Informed" Conceptions of Scientific Inquiry, Inquiry Teaching, and Inquiry Learning

\begin{tabular}{lcc}
\hline Participants & $\begin{array}{c}\text { "Uninformed/traditional } \\
\text { conception" } \\
\text { (n) }\end{array}$ & $\begin{array}{c}\text { "Partially informed } \\
\text { conception" } \\
\text { (n) }\end{array}$ \\
\hline Science teachers & 14 & 4 \\
Head teachers & 10 & 2 \\
Circuit supervisors & 3 & 1 \\
Science coordinators & 1 & 2 \\
Directors/deputy directors of education & 3 & 1 \\
Total & 31 & 10 \\
\hline
\end{tabular}

\subsection{Conceptions of Scientific Inquiry}

Table 3 shows that all the teachers and educational administrators held either "uninformed/traditional" or "partially informed" conceptions of scientific inquiry with none of them holding fully informed conception. 


\subsubsection{Uninformed/Traditional Conceptions of Scientific Inquiry}

Over three-quarters 31(75.6\%) of the participants held uninformed conceptions of scientific inquiry. They consist of 14 science teachers (ST1, ST2, ST3, ST4, ST5, ST6, ST7, ST8, ST9, ST11, ST12, ST13, ST14, and ST15), 10 head teachers (HT2, HT4, HT5, HT6, HT7, HT8, HT9, HT10, HT11, and HT12), 3 circuit supervisors (CS2, CS3, and CS4), a science coordinator (SC1), 2 deputy directors (DD2 and DD3) and a director of education (DD4) (Table 3). When asked to describe their conceptions of scientific inquiry most of them said it is a practical (Table 1) subject involving students in step-by-step activities to understand science concepts.

In this case students are taken through activities, step-by-step. As they go through activities step-by-step, they understand concepts that are being taught. (DD3)

Participants in this category could not differentiate actual science (scientific inquiry) from school science (science education) in which students practice and learn the activities and thinking processes of scientists. Again, many interviewees in this category conceived scientific inquiry as involving "research" (Table 1).

My understanding of science inquiry-based activities is that students are made to make inquiries based on the lesson to be taught. That is, do their own "research", get deeper understanding of what they are about to be taught, ... (ST9)

Research as used by participants in this category means students reading about already known information from books and internet, and seeking information from friends, parents, and others to contribute to traditional science lessons.

Suppose next week I will teach the topic "air", some students can go and ask their colleagues at home ... Other students can go on the internet and make their own "research". On the day of the lesson, the students will then bring out their ideas about the topic. (ST13)

However, "research" as used by participants in this category is completely different from research conducted by actual scientists. Research conducted by actual scientists are driven by identified questions that may or may not lead to hypothesis testing; do not follow a single set of steps for investigations; adopt procedures that are guided by the driving questions; and produce results that are influenced by the procedures. In actual scientific research, different scientists following the same procedures may come up with different results; conclusions drawn are consistent with the data collected; scientific data are treated differently from evidence; and explanations are developed from combination of the data and prior knowledge. The manner participants in the "uninformed/traditional" category used the term research is inaccurate. These factual inaccuracies exposed their uninformed conceptions of scientific inquiry.

Some participants in the "uninformed/traditional" category attempted to describe constructivist perspectives of scientific inquiry. They made vague references to "identification and solution of problem" and "observation and experimentation" (Table 1) to understand phenomena in the environment.

\section{In science you make observations of phenomena and find solutions to problems. (ST11)}

We are in the global village and this has to do with science. ... Everything deals with experimenting and activities in which one has to inquire before he comes to know. (ST1)

However, these participants could not provide details about how scientists identify problems and solve them. They were also unable to provide details about the processes involved in science experimentation.

\subsubsection{Partially Informed Conceptions of Scientific Inquiry}

Table 3 shows that about one-quarter 10(24.4\%) of the participants held partially informed conceptions of scientific inquiry. They consist of 4 science teachers (ST10, ST16, ST17, and ST18), 2 head teachers (HT1 and HT3), a circuit supervisor (CS1), 2 science coordinators (SC2 and SC3), and a deputy director of education (DD1). They articulated conceptions that contain some essential elements of inquiry. When asked to describe scientific inquiry they said it involves identification and solution of problems, and research (Table 1).

Inquiry ... is to ask why and how of natural phenomena. It is through asking questions ... that one can seek knowledge ... but not through speculation. (DD1)

Science involves research and practical activities. So, as things keep ... changing there is the need for research. (HT1)

These responses suggest that scientific inquiry involves deliberate research into natural phenomena, and that scientific research are driven by questions. The responses further suggest that valid scientific knowledge is obtained 
through research and not speculation, and that research must keep pace with changing scientific knowledge (tentativeness of science).

\subsection{Conceptions of Inquiry-Based Science Teaching}

Table 3 shows that all the participants held either "uninformed/traditional" or "partially informed" conceptions of inquiry-based science teaching with none of them holding fully informed conception.

\subsubsection{Uninformed/Traditional Conceptions of Science Teaching}

Over three-quarters $31(75.6 \%)$ of the interviewees held traditional conceptions of science teaching (Table 3). When asked to describe inquiry teaching, they said it involves practical hands-on activities where teachers demonstrate (Table 1) phenomena for students to see and then allow the students to have a feel of it.

Teachers ... should teach science as practical not as theory. The teacher should carry out demonstrations for students to see and hear and allow them to practice it. (CS2)

They also conceived inquiry teaching as a process where teachers gather materials and try out activities (Table 1) to see if the desired results can be achieved.

If the teacher is going to perform an experiment in a lesson, he needs to perform the experiment at home to know if he can get the correct answer. (DD3)

However, these practices are traditional science teaching strategies conducted to verify content already taught in classroom. In these practices, teachers plan and design all the procedures with no or minimal students' involvement.

Again, participants in the "uninformed/traditional" category conceived inquiry teaching as involving lectures and content delivery (Table 1) for students to receive.

The role the teacher should play is to get the necessary information and pass it on to the pupils. (HT6)

When asked to describe inquiry roles of teachers, participants in this category said teachers in inquiry-based instruction guide, facilitate, monitor, supervise, moderate, lead, motivate, direct, and coach (Table 1) students.

During inquiry teaching the teacher serves as a guide, motivator, and leader. (CS3)

The teacher is supposed to ... moderate and direct the students. (SC1)

While these terms represent proper inquiry roles of teachers, many participants in this category made vague references to these terms without providing details about how teachers assume such roles. Participants who attempted to provide details ended up describing traditional teacher roles of giving instructions, rules and regulations, and safety procedures (Table 1) for students to follow.

The role of the teacher is to guide the children. The teacher gives students rules and regulations on what to do and what not to do. (HT11)

By guidance I mean students should be given the instructions and steps necessary to perform experiments. (ST3)

The manner participants in the "uninformed/traditional" group used terms such as coaching, guiding, facilitating, and directing is inaccurate. These factual inaccuracies revealed their uninformed conceptions of inquiry teaching, but their traditional views of science teaching.

\subsubsection{Partially Informed Conceptions of Inquiry-Based Science Teaching}

About one-quarter 10(24.4\%) of the participants held partially informed conceptions of inquiry teaching (Table 3). When asked to describe inquiry teaching, they said it involves real-world activities in which students are taken on field trips (Table 1) to experience real science and first-hand information.

The teaching should involve children in seeing real objects and organisms. When students go around in the environment, they get to know living things and non-living things. They get to know the habitats of some living things and conditions that make the living things adapt comfortably in the habitats. (HT3)

Children learn by experience ..., if the lesson is activity-based, you allow the child to use all their senses in learning. By using inquiry approach, the teacher allows the children's cognitive domain to be active and to find out things for themselves. (SC2)

These responses show that the participants understand inquiry teaching as active engagement of students in science lessons. The participants also understand that inquiry teaching involves facilitating students to use all their senses to manipulate and interact with materials, and use cognitive strategies to construct knowledge for themselves. 
When asked to describe inquiry roles of teachers, participants in this category also said teachers' inquiry roles include guiding, facilitating, monitoring, leading, supervising, motivating, directing, and coaching (Table 1) students.

The teacher facilitates, he gives students direction as to what they should do. He then allows the children to come out with their own solution. (CS1)

The teacher's role is to monitor and facilitates but the actual work is supposed to be done by the learner. (SC2)

However, unlike participants in the "uninformed/traditional" category, participants in the "partially informed" group provided fairly accurate descriptions of these inquiry roles. They said teachers' inquiry roles includes granting autonomy (Table 1) for students to engage in activities, with the teacher coming in only when students are in difficulties or it is necessary to do so.

When the students are finding the problem to be difficult then the teacher comes in and gives them direction as to what to do and where to go. (CS1)

Again, participants in this category said teachers in inquiry instruction guide, facilitate, and motivate students to prevent them from becoming frustrated and abandoning investigations.

If students are allowed to do investigations on their own it gets to a point when they may not know what to do and they become discouraged. So, teachers are to serve as guides to the students. (SC3)

Although interviewees in the "partially informed" group expressed fairly accurate conceptions of inquiry teaching, they did not fully articulate how teachers lead students through extensive questioning and scaffolding to plan and design investigations, collect and record data, examine and evaluate the quality of data, and interpret data to develop explanations for phenomena.

\subsection{Conceptions of Inquiry-Based Science Learning}

Table 3 shows that all the teachers and educational administrators held either "uninformed/traditional" or "partially informed" conceptions of inquiry learning, with none of them holding fully informed conception.

\subsubsection{Uninformed/Traditional Conceptions of Science Learning}

Over three-quarters 31(75.6\%) of the participants held uninformed/traditional conceptions of science learning (Table 3). When asked to describe inquiry learning, most participants in this category said it involves child-centred and student-centred activities, with students having autonomy (Table 1) to actively involve in lessons.

The lesson must be child-centred. When students are involved in the lesson, they will understand better. (CS2)

While student-centred, child-centred, students' autonomy, and students' involvement are terms associated with constructivist views of learning, participants in the "uninformed/traditional" category used these terms in reference to traditional learning experiences in which students practice activities after teacher demonstrations, and interact with materials just to have a feel of them.

Children should be involved in the lesson. The teacher should carry out demonstrations for the children to see and hear, and allow them to practice it. (CS2)

Participants in this category also used child-centred, student-centred, students' autonomy, and students' involvement to refer to traditional science learning experiences in which students follow instructions and procedures to perform hands-on activities and arrive at predetermined answers.

The students abide by rules and regulations, and limit themselves to the examples given by the teacher in conducting their experiments. In this way the students may come out with the desired results in the end. (HT11)

The use of student-centred, child-centred, student autonomy, and students' involvement in reference to traditional learning experiences are factually inaccurate. These inaccuracies revealed the participants' uninformed conceptions of inquiry learning but, their traditional conceptions of science learning.

Again, many interviewees in this category said students in inquiry learning engage in "research" (Table 1).

During inquiry-based science learning students should be involved in making "research" and activities in the class. (ST9)

However, "research" as used by participants in this group means students reading already known information from 
books and internet, and seeking information from their friends, parents, and resource persons.

... students have to read something about what they are going to do, so that they will have fair idea about it. In this way, whatever the teacher say will not be strange to them. They also have to read ahead of the teacher so that they can move along with the teacher. (ST12)

This "research" is done to equip students with the necessary information to answer questions during traditional science instruction in which, teachers elicit students' prior knowledge and link it to the next lecture. However, readings done by students in traditional science instruction is different from references done by students in inquiry-based learning. Students in inquiry learning make references from books, internet, articles, etc to check if explanations they have constructed from their investigations are consistent with existing scientific knowledge.

Some participants in the "uninformed/traditional" category attempted to describe constructivist views of learning. They said students' roles in inquiry are to explore, identify and solve problems, present results and findings, and engage in critical thinking (Table 1).

During inquiry, the child would like to explore and know. The child becomes curious and would like to know what make things function. (CS3)

Children ... should be free to interact with materials that have been provided. It shouldn't be forced on them ... The role of students is to think critically about questions the teacher has asked. (DD2)

... students ... should be thinking about what is likely to happen next. Students should be able to guess (hypothesize) the final outcome of their investigations or activities. (DD3).

However, the participants made vague references to these inquiry features without providing details about how students engage in explorations, identification and solution of problems, presentation of results and findings, and critical thinking.

\subsubsection{Partially Informed Conceptions of Science Learning}

About one-quarter $10(24.4 \%)$ of the participants held partially informed conceptions of inquiry-based science learning (Table 3). When asked to describe inquiry learning, they said it is a child-centred (Table 1) activity in which students actively participate in investigations and come out with answers to leading questions.

The children are to take active part in activities and come out with solution to the problem that have been given to them by the teacher or what they themselves set out to find. (CS1)

Participants in the "partially informed" category also said that students in inquiry learning engage in in-depth discussions to plan and design investigation procedures (Table 1) and construct knowledge.

... after introducing the topic to the children, you [the teacher] give them the chance to bring out their views about how they can go about the activity. The children will bring out all their ideas, and will even suggest how the activity should be designed and conducted. (HT3)

The interviewees also said that inquiry roles of students involve asking scientifically-oriented questions and collecting and recording data (Table 1).

The students are to probe and do more questioning. (DD1)

The students need to do a lot of recording to help them gather their information as they move along, else they may forget the information or data, and the whole activity will be disorganized. (SC3)

Again, interviewees in the "partially informed" category said that students in inquiry investigations "research" (Table 1) for information from books, internet, and other sources to help them answer leading questions or solve problems driving the investigations.

When the teacher gives students the leading question, the children look for information from other sources. If the children want to "research" into books, the teacher tells them books that will be helpful. (DD1)

The participants also said that students in inquiry learning work in groups, engage in discussions, and share ideas to construct their own knowledge (Table 1).

If students are in groups, all of them are to take part, share ideas, contribute, bring suggestions, and criticize their friends' ideas. Not criticisms per se but offer suggestions, weigh the suggestions or contributions of individuals, and then come up with the best solution to the problem. (ST17)

Again, interviewees in the "partially informed" category said that inquiry-based science learning does not occur in 
the classroom alone, but also in the field (Table 1).

Inquiry learning is not limited to only classroom work, but it can even take place outside the classroom ... So, scientific inquiry is not a straightforward thing that follows a certain procedure in the classroom. (ST17)

\section{Discussion}

Results from this study show that all the teachers and educational administrators held either uninformed/traditional or partially informed conceptions of scientific inquiry, inquiry teaching, and inquiry learning with none of them holding fully informed conception. Most researchers acknowledge that "teachers need to develop robust understandings of scientific inquiry" (Crawford, 2007, p. 636) as a necessary prerequisite for planning and enacting inquiry-based instruction (Abd-El-Khalick, 2013). Clearly, the aforementioned finding suggests that conceptions of many teachers and educational administrators in this study context, like the conceptions of teachers and administrators in similar contexts, do not promote but constrain inquiry-based science teaching in junior high schools.

Most of the teachers and educational administrators could not differentiate actual science (scientific inquiry) from school science (science education). They conceived science teaching as delivery of knowledge accompanied by verification hands-on activities. They also conceived science learning as reception of knowledge and manipulation of materials to practice activities demonstrated by the teacher. These findings are similar to findings prior to but differ from findings after professional developments and methods courses in other contexts (Choi \& Ramsey, 2009; Crawford, 2007; Haefner \& Zembal-Saul, 2004; Maeng et al., 2020). While the effectiveness of inquiry-based instruction is widely acknowledged and many countries are seeking to adopt and implement this pedagogical approach, the present findings and others (Dudu \& Vhurumuku, 2020; Mokiwa \& Nkopodi, 2014; Mugabo, 2012) suggest that there are preservice and in-service teachers in many contexts without or with little clues about the activities and thinking processes used to generate explanations for natural phenomena.. Empirical evidence also shows that many teachers in this study context, like teachers in similar contexts, have no or little clues about how to structure knowledge and create authentic learning environments that convey to students images of scientific practices resembling the work of actual scientists. Again, findings in this study suggest that there are educational administrators in many contexts without or with little clues about how to provide the mentorship, support, and feedback required for inquiry teaching and learning in schools.

Results from this study show also that participants' conceptions of scientific inquiry reflect (connect) in their conceptions of science teaching and learning. Participants without informed conceptions of scientific inquiry held traditional conceptions of science teaching and learning, while participants with partial conceptions of scientific inquiry held partially informed conceptions of inquiry teaching and learning. This evidence reinforces earlier findings in this study, that, it would be difficult, if not impossible, for teachers without informed conceptions of inquiry to help students understand and develop the abilities to conduct inquiry. This finding aligns with the theoretical assumption that teachers' conceptions of scientific inquiry manifest in their understandings of science teaching and learning (Aguirre et al., 1990; Crawford, 2007). While most previous studies focused on examining participants' conceptions of inquiry teaching (Akerson et al., 2012; Dudu \& Vhurumuku, 2020; Mugabo, 2012; Ssempala, 2017), the current study and few others (Aguirre et al., 1990; Haefner \& Zembal-Saul, 2004) went further to explore connections between individuals' conceptions of scientific inquiry, inquiry teaching, and inquiry learning.

Abel and Smith (1994) and Haefner and Zembal-Saul (2004) suggested that some teachers' inability to distinguish actual science from school science could be due to the studies being conducted in educational contexts. However, evidence from this study show that most of the teachers and educational administrators exhibited uninformed conceptions because they had never been exposed to and had never experienced inquiry-based science teaching and learning when they were students. Consequently, they lack clear images of the activities and thinking processes that scientists employ to inquire into the natural world. Most participants in this study experienced traditional science instruction when they were students in elementary and high schools. Therefore, they only have images of traditional science teaching practices.

What my teachers were doing is what I am also doing now. In fact, I have not seen any change at all. (ST1)

Most researchers acknowledge that traditional science education experiences teachers had when they were students strongly influence the formation of their understandings of science and science teaching (Abell \& Smith, 1994; Choi \& Ramsey, 2009).

In other contexts, explicit-reflective inquiry-based methods courses and professional developments are designed to 
promote teachers' conceptions and abilities to enact inquiry teaching (Akerson et al., 2012; Haefner \& Zembal-Saul, 2004). However, more than three-quarters $34(82.9 \%)$ of the participants in this study said in-service trainings given to teachers are designed to treat challenging topics identified in the syllabus but, are not inquiry-based experiences.

We identify areas or topics in the syllabus that teachers have difficulties teaching in classrooms. We then mobilise the science teachers at one place and take them through resolving those difficulties. (SC3)

The fact that teachers and educational administrators in many contexts had never experienced inquiry teaching and learning when they were students and, are presently not given inquiry-based in-service trainings is worrisome. This is because they will continue to hold onto the uninformed conceptions of scientific inquiry and traditional conceptions of teaching and learning which, would become major constrain to the success of current basic science education reform initiatives in these contexts. in.

\section{Conclusions}

Findings from this study and others suggest that there are teachers and educational administrators in many contexts with uninformed conceptions of inquiry and traditional conceptions of teaching and learning which, constrain inquiry-based science instruction in JHSs. These uninformed/traditional conceptions developed because of the absence or rare occurrence of inquiry-based instructional experiences in many schools, teacher training institutions, and in-service trainings. One implication of the current findings is that efforts aimed at adopting and implementing inquiry-based science curricula in many countries may not produce the desired results. Another implication is that the aim of using inquiry pedagogy to produce scientifically literate graduates may not be fully realised. Based on findings from this study and others we recommend sustained engagement of integrated science teachers and educational administrators in inquiry-based professional developments at the school and district levels to promote effective teaching and support for inquiry in JHSs. To ensure a growing population of teachers with informed conceptions and abilities to implement inquiry instruction in classrooms, we also recommend reform in preservice science teacher education that embraces inquiry-based practices. More studies are required to examine successes and challenges associated with helping teachers in the current study context to learn inquiry-based science teaching practices.

\section{References}

Abd-El-Khalick, F. (2013). Teaching With and About Nature of Science, and Science Teacher Knowledge Domains. Science \& Education, 22(9), 2087-2107. https://doi.org/10.1007/s11191-012-9520-2

Abell, S. K., \& Smith, D. C. (1994). What is science?: Preservice elementary teachers conceptions of the nature of science. International Journal of Science Education, 16(4), 475-487.

Aguirre, J. M., Haggerty, S. M., \& Linder, C. J. (1990). Science-teachers' conceptions of science, teaching and learning: a case study in preservice science education. International Journal of Science Education, 12(4), 381-390.

Akerson, V. L., Donnelly, L. A., Riggs, M. L., \& Eastwood, J. L. (2012). Developing a Community of Practice to Support Preservice Elementary Teachers' Nature of Science Instruction. International Journal of Science Education, 34(9), 1371-1392. https://doi.org/10.1080/09500693.2011.639100

Anamuah-Mensah, J. (2012). Foreword. In A. Asabere-Ameyaw, G. J. S. Dei, \& K. Raheem (Eds.), Contemporary Issues in African Sciences and Science Education (pp. ix-xii). Rotterdam, The Netherlands: Sense Publishers. https://doi.org/10.1007/978-94-6091-702-8

Anderson, R. D. (2002). Reforming science teaching: What research says about inquiry. Journal of Science Teacher Education, 13(1), 1-12. https://doi.org/10.1023/A:1015171124982

Bartos, S. A., \& Lederman, N. G. (2014). Teachers' knowledge structures for nature of science and scientific inquiry: Conceptions and classroom practice. Journal of Research in Science Teaching, 51(9), 1150-1184. https://doi.org/10.1002/tea.21168

Bell, C., Shepardson, D., Harbor, J., Klagges, H., Burgess, W., Meyer, J., \& Leuenberger, T. (2003). Enhancing Teachers' Knowledge and Use of Inquiry Through Environmental Science Education. Journal of Science Teacher Education, 14(1), 49-71.

Capps, D. K., \& Crawford, B. A. (2013). Inquiry-Based Professional Development: What does it take to support 
teachers in learning about inquiry and nature of science? International Journal of Science Education, 35(12), 1947-1978. https://doi.org/10.1080/09500693.2012.760209

Chabalengula, V. M., \& Mumba, F. (2012). Inquiry-based science education : A scenario on Zambia' s high school science curriculum. Science Education International, 23(4), 307-327.

Choi, S., \& Ramsey, J. (2009). Constructing Elementary Teachers' Beliefs, Attitudes, and Practical Knowledge Through an Inquiry-Based Elementary Science Course. School Science and Mathematics, 109(6), 313-324. https://doi.org/10.1111/j.1949-8594.2009.tb18101.x

Cohen, L., Manion, L., \& Morrison, K. (2007). Research Methods in Education (6th ed.). London: Taylor \& Francis. https://doi.org/10.4324/9780203029053

Crawford, B. A. (2000). Embracing the essence of inquiry: New roles for science teachers. Journal of Research in Science Teaching,
https://doi.org/10.1002/1098-2736(200011)37:9<916::AID-TEA4>3.0.CO 2 - 2 ,

Crawford, B. A. (2007). Learning to teach science as inquiry in the rough and tumble of practice. Journal of Research in Science Teaching, 44(4), 613-642. https://doi.org/10.1002/tea.20157

Creswell, J. W. (2009). Research Design: Qualitative, Quantitative, and Mixed methods approaches (4th ed.). Thousand Oaks, California: SAGE Publications, Inc.

Curriculum Research and Development Division [CRDD]. (2007). Teaching syllabus for integrated science: Junior high school. Accra, Ghana: Curriculum Research and Development Division.

Curriculum Research and Development Division [CRDD]. (2012). National syllabus for integrated science: Junior high school. Accra, Ghana: Curriculum Research and Development Division.

Dogan, N., \& Abd-El-Khalick, F. (2008). Turkish grade 10 students' and science teachers' conceptions of nature of science: A national study. Journal of Research in Science Teaching, 45(10), 1083-1112. https://doi.org/10.1002/tea.20243

Dudu, W. T., \& Vhurumuku, E. (2020). Teachers' Practices of Inquiry When Teaching Investigations : A Case Study. JST, 23(6), 579-600.

Fitzgerald, M., Danaia, L., \& McKinnon, D. H. (2019). Barriers Inhibiting Inquiry-Based Science Teaching and Potential Solutions: Perceptions of Positively Inclined Early Adopters. Research in Science Education, 49(2), 543-566. https://doi.org/10.1007/s11165-017-9623-5

Furtak, E. M., Seidel, T., Iverson, H., \& Briggs, D. C. (2012). Experimental and Quasi-Experimental Studies of Inquiry-Based Science Teaching: A Meta-Analysis. Review of Educational Research, 82(3), 300-329. https://doi.org/10.3102/0034654312457206

Haefner, L. A., \& Zembal-Saul, C. (2004). Learning by doing? Prospective elementary teachers' developing understandings of scientific inquiry and science teaching and learning. International Journal of Science Education, 26(13), 1653-1674. https://doi.org/10.1080/0950069042000230709

Hume, A., \& Coll, R. (2010). Authentic student inquiry: The mismatch between the intended curriculum and the student-experienced curriculum. Research in Science and Technological Education, 28(1), 43-62. https://doi.org/10.1080/02635140903513565

Ireland, J. E., Watters, J. J., Brownlee, J., \& Lupton, M. (2012). Elementary Teacher's Conceptions of Inquiry Teaching: Messages for Teacher Development. Journal of Science Teacher Education, 23(2), 159-175. https://doi.org/10.1007/s10972-011-9251-2

Jacob, S. A., \& Furgerson, S. P. (2012). The qualitative report writing interview protocols and conducting interviews: Tips for students new to the field of qualitative research. The Qualitative Report, 17(42), 1-10.

Johnson, C. C. (2007). Technical, political and cultural barriers to science education reform. International Journal of Leadership in Education, 10(2), 171-190. https://doi.org/10.1080/13603120601097470

Lederman, J. S., \& Lederman, N. G. (2017). International collaborative investigation of beginning seventh grade students' understandings of scientific inquiry. Enseñanza de Las Ciencias, (Extra), 3569-3574.

Lederman, J. S., Lederman, N. G., Bartos, S. A., Bartels, S. L., Meyer, A. A., \& Schwartz, R. S. (2014). Meaningful assessment of learners' understandings about scientific inquiry - The views about scientific inquiry (VASI) questionnaire. Journal of Research in Science Teaching, 51(1), 65-83. https://doi.org/10.1002/tea.21125 
Lee, C. K., \& Shea, M. (2016). An Analysis of Pre-service Elementary Teachers' Understanding of Inquiry-based Science Teaching. Science Education International, 27(2), 219-237.

Lotter, C., Harwood, W. S., \& Bonner, J. J. (2006). Overcoming a Learning Bottleneck: Inquiry Professional Development for Secondary Science Teachers. Journal of Science Teacher Education, 17(3), 185-216. https://doi.org/10.1007/s10972-005-9002-3

Maeng, J. L., Whitworth, B. A., Bell, R. L., \& Sterling, D. R. (2020). The effect of professional development on elementary science teachers' understanding, confidence, and classroom implementation of reform-based science instruction. Science Education, 104(2), 326-353. https://doi.org/10.1002/sce.21562

Mohammed, S. M., Amponsah, K. D., Ampadu, E., \& Kumassah, E. K. (2020). Extent of Implementation of Inquiry-based Science Teaching and Learning in Ghanaian Junior High Schools. Eurasia Journal of Mathematics, Science and Technology Education, 16(12), 1-15. https://doi.org/10.29333/ejmste/9373

Mokiwa, H. O., \& Nkopodi, N. (2014). Inquiry-Based Teaching in Physical Science: Teachers' Instructional Practices and Conceptions. Mediterranean Journal of Social Sciences, 5(23), 1074-1082. https://doi.org/10.5901/mjss.2014.v5n23p1074

Mugabo, R. L. (2012). Introduction of Inquiry-based Science Teaching in Rwandan Lower Secondary Schools: Teachers 'attitudes and perceptions, (Unpublished Doctoral Dissertation). University of KwaZulu-Natal.

National Research Council [NRC]. (1996). National science Education standards. Washington D.C.: National Academcy Press.

National Research Council [NRC]. (2000). Inquiry and the national science education standards: A guide for teaching and learning. In Social Sciences. Washington D.C.: National Academcy Press.

National Research Council [NRC]. (2012). A framework for K-12 science education: Practices, crosscutting concepts, and core ideas. Washington D.C.: National Academcy Press.

Shumba, O. (1999). Critically interrogating the rationality of Western science vis-à-vis scientific literacy in non-Western developing countries. Zambezia, 26(1), 55-75.

Ssempala, F. (2017). Science Teachers understsanding and practice of inquiry-based instruction in Uganda. (Syracuse University). Syracuse University. $\quad$ Retrieved from http://surface.syr.edu/etd\%0Ahttp://surface.syr.edu/etd/690

Stone, B. (2020). Understanding the Influence of Teacher-Directed Scientific Inquiry on Students' Primal Inquiries in Two American Science Classrooms. Journal of Research in Childhood Education, 00(00), 1-17. https://doi.org/10.1080/02568543.2020.1718807

Syer, C. A., Chichekian, T., Shore, B. M., \& Aulls, M. W. (2013). Learning "to do" and learning "about" inquiry at the same time: Different outcomes in valuing the importance of various intellectual tasks in planning, enacting, and evaluating an inquiry curriculum. Instructional Science, 41(3), 521-537. https://doi.org/10.1007/s11251-012-9242-5

Toolin, R. E. (2004). Striking a Balance Between Innovation and Standards: A Study of Teachers Implementing Project-Based Approaches to Teaching Science. Journal of Science Education and Technology, 13(2), 179-187. https://doi.org/10.1023/b:jost.0000031257.37930.89

\section{Copyrights}

Copyright for this article is retained by the author(s), with first publication rights granted to the journal.

This is an open-access article distributed under the terms and conditions of the Creative Commons Attribution license (http://creativecommons.org/licenses/by/4.0/). 